\title{
Metal Uptake and Physiological Changes in Lemna gibba Exposed to Manganese and Nickel
}

\author{
Zeynep Banu Doganlar ${ }^{1}$, Seher Cakmak ${ }^{2} \&$ Telat Yanik ${ }^{3}$ \\ ${ }^{1}$ Department of Biology, Faculty of Science and Art, Agri Ibrahim Cecen University, Agri, Turkey \\ ${ }^{2}$ Ministry of Food, Agriculture and Livestock Agri Provincial Directorate, Dogubayazit, Agri, Turkey \\ ${ }^{3}$ Rectorate of Agri Ibrahim Cecen University, Agri, Turkey \\ Correspondence: Zeynep Banu Doganlar, Science and Art Faculty, Agri Ibrahim Cecen University, Agri, Turkey. \\ Tel: 90-472-215-6554. E-mail: zdoganlar@yahoo.com.tr
}

Received: May 7, 2012 Accepted: May 30, 2012 Online Published: June 26, 2012

doi:10.5539/ijb.v4n3p148 URL: http://dx.doi.org/10.5539/ijb.v4n3p148

\begin{abstract}
We investigated the effects of manganese $(\mathrm{Mn})$ and nickel $(\mathrm{Ni})$ stress on pigment (total chlorophyll and carotenoid), total soluble protein content and antioxidant enzyme [superoxide dismutase (SOD) guaiacol peroxidase (POD) and catalase (CAT)] activities in Lemna gibba under laboratory conditions. L. gibba was treated with exposures of $\mathrm{Mn}$ and $\mathrm{Ni}$ separately at $0.25,1,4$ and $16 \mathrm{mg} / \mathrm{L}$ concentrations for 72 hours at $24 \mathrm{~h}$ intervals. The results of the present study showed that the physiological status of $L$. gibba was affected by Mn and $\mathrm{Ni}$ exposure. $\mathrm{Mn}$ and $\mathrm{Ni}$ accumulations showed increases in a concentration dependent manner. The amount of accumulated $\mathrm{Mn}$ was higher than $\mathrm{Ni}$ at all concentrations and exposure times. Ni caused strong inhibition on the total chlorophyll and carotenoid amounts than $\mathrm{Mn}$. The increase in the total protein content was more evident in Mn-exposed plants. The highest increase in SOD activity was evidenced in Ni-treated plants for all exposure times. However, the stimulating effect of Mn on CAT and POD activities was more evident than of Ni (except for 72. h). Based on these results it is concluded that Ni was found to be more toxic to L. gibba than Mn. Additionally, $L$. gibba may be used for phytoremediation of $\mathrm{Mn}$ in polluted aquatic environments.
\end{abstract}

Keywords: Lemna gibba, heavy metal stress, manganese, nickel, superoxide dismutase, catalase, peroxidase, pigment

\section{Introduction}

Aquatic environments usually serve as the last destination for agricultural, mining, urban and industrial wastes. Therefore, toxic heavy metals and other pollutants are generally found in high concentrations in these ecosystems (Megateli et al., 2009). Aquatic plants accumulate toxic heavy metals and other aquatic pollutants in high amounts (Henner \& Jahnssen-Mommen, 1993; Prasad et al., 2001). Hence, they are generally used as model plants for phytoremediation studies and the determination of the effects of heavy metals on physiological responses of plants. It has been reported that because of heavy metal toxicity, increasing cellular reactive oxygen species, such as superoxide anion, hydroxyl anion and hydrogen peroxide cause oxidative stress. The reactive oxygen species are deactivated by enzymatic (superoxide dismutase, catalase, ascorbate peroxidase, guaiacol peroxidase and glutathione reductase) and non-enzymatic (glutathione, ascorbic acid, phenolic compounds and tocopherol) antioxidant systems (Parvaiz et al., 2008; Azqueta et al., 2009).

Manganese (Mn) and nickel (Ni) are essential micronutrients for plant growth and development. $\mathrm{Mn}$ is an important element for photosynthesis and enzyme metabolism (Millalea et al., 2010). Ni is a cofactor for urease and eight Ni-containing enzymes present in plants and bacteria (Watt \& Ludden, 1999; Chowdry et al., 2008; Maleva et al., 2009). These elements can cause some physiological and biochemical changes at their toxic concentrations in aquatic environments. Excess $\mathrm{Mn}$ and $\mathrm{Ni}$ cause changes in the activities of antioxidant enzymes such as SOD (superoxide dismutase), catalase (CAT) and guaiacol peroxidase (POD) (Demirevska-Kepova et al., 2004; Maleva et al., 2009). Inhibition of photosynthesis by a decrease in pigment contents (chlorophyll a, chlorophyll b carotenoids) under excess Mn (Vicia faba, Pisum sativum, Hordeum vulgare) and $\mathrm{Ni}$ (L. gibba, Elodea canadensis, Spirodela polyrhiza) were determined in previous studies (Demirevska-Kepova et al., 2004; Zengin \& Munzuroglu, 2005; Fagasova et al., 2006; Rezai \& Farboodina, 
2008; Maleva et al., 2009; Appenroth et al., 2010; Radic et al,. 2010; Arya \& Roy, 2011).

Although many aquatic plants were used in biomonitoring of aquatic environments, $L$. gibba is among the plants that react too early to the changes in water quality. Therefore, in this study, the accumulation and phytotoxic effects of $\mathrm{Mn}$ and $\mathrm{Ni}$ were determined in L. gibba in a concentration and time dependent manner. In order to show the phytotoxic effects of $\mathrm{Mn}$ and $\mathrm{Ni}$ on L. gibba, changes in the amounts of photosynthetic pigments (total chlorophyll and carotenoid) and total soluble proteins, activities of antioxidant enzymes (SOD, POD and CAT) and metal accumulation levels were determined.

\section{Materials and Methods}

\subsection{Plant Material and Metal Treatment}

L. gibba plants were collected from natural earthen ponds in the Malazgirt/Mus (Turkey) and transported to the laboratory in plastic water tanks (5 L). Prior to the heavy metal treatment, plants were washed in tap water and kept in $1 / 10$ Hoagland culture solution under controlled conditions (temperature $25 \pm 2^{\circ} \mathrm{C}$; light/dark cycles $16 / 8 \mathrm{~h}$ and light intensity of $115 \mu \mathrm{molm}^{2} \mathrm{~s}^{-1}$ ) for acclimatization (Hoagland, 1950). After one week of cultivation, Mn and $\mathrm{Ni}$ were added to the growth media in doses of $0.25,1,4$ and $16 \mathrm{mg} / \mathrm{L}$ for 24,48 and 72 hours. After heavy metal exposure, plant samples were collected, washed and stored in a $-86{ }^{\circ} \mathrm{C}$ deep freezer (New Brunswick, Eppendorf Company) for subsequent steps of the chemical analyses. Both controls and heavy metal-treated experiments were analyzed in triplicate.

\subsection{Determination of Heavy Metal Contents}

Dry tissues of $L$. gibba were digested with $8 \mathrm{~mL} 65 \%$ nitric acid solution with Milestone SK 10 microwave digestion system (Power: $1500 \mathrm{~W}$, Time $15 \mathrm{Min}$, Temp 1: $180^{\circ} \mathrm{C}$, Temp 2: $100^{\circ} \mathrm{C}$, Pressure: 45 bar) (HPR-FO-08, Aquatic Plants, Milestone, Application book). Digested solutions were diluted with deionized water and the final volume of the solution was adjusted to $10 \mathrm{~mL}$. After dilution, the digests were analyzed for $\mathrm{Mn}$ and Ni. Metal concentrations were determined by inductively coupled plasma mass spectrometry (ICP- MS, Thermo, X-II series) (Doganlar and Atmaca, 2012).

\subsection{Determination of Pigment Content}

Pigment contents of control and metal-treated plants were determined according to Doganlar (2012). Briefly, 200 $\mathrm{mg}$ fresh plant tissue was homogenized in $8 \mathrm{ml}$ acetone $(80 \%)$ with a homogenizer (Wiggenhauser, D500). The homogenate was centrifuged at 3,000 rpm, and the absorbance of the supernatants was measured at 645,652 , 663 and $470 \mathrm{~nm}$ (Uv-vis Spectrophotometer, Shimadzu V-1800). The quantities of pigments were calculated as described by Lichtenthaler and Wellburn (1983).

\subsection{Enzyme Extraction and Assays}

Extractions: $1 \mathrm{~g}$ fresh plant tissue was homogenized in $5 \mathrm{~mL}$ cold Na-P buffer (pH: 7.2). Obtained homogenate was centrifuged at $14,000 \mathrm{rpm}$ for $25 \mathrm{~min}$ at $4^{\circ} \mathrm{C}$. The supernatant was used for determination of both total soluble protein content and antioxidant enzyme activities. A Thermo Scientific Multiskan ${ }^{\circledR}$ FC Microplate Photometer was used for the determination of the absorbances in the enzymatic analysis.

Guaiacol peroxidase (EC 1.11.1.7) activity was determined according to Birecka et al. (1973) and Doganlar and Atmaca (2011). The total POD activity was expressed as $\triangle \mathrm{A} / \mathrm{g}$ F.W. min.

Superoxide dismutase (EC 1.15.1.11) activity was assessed by the nitrobluetetrazolium (NBT) photoreduction method (Porgali \& Yurekli, 2005).

The total soluble protein contents of L. gibba under heavy metal treatment were determined according to Bradford (1976).

Catalase (EC 1.11.1.6) activity was measured according to Aebi (1984). The reaction mixture contained K-P buffer $(50 \mathrm{mM}), 15 \mathrm{mM} \mathrm{H}_{2} \mathrm{O}_{2}$ (hydrogen peroxide) and enzyme extract. The reaction was started with the addition of $\mathrm{H}_{2} \mathrm{O}_{2}$ and decrease in the absorbance was measured for $1 \mathrm{~min}$.

\subsection{Statistical Analysis}

Differences in the plants' physiological parameters under heavy metal effects were compared using ANOVA with means separation by Duncan's test using SPSS 15 software at a significance level of $P \leq 0.05$. Correlations between the metal concentrations and the physiological parameters were analyzed by a bivariate correlation test with Pearson correlation coefficient and a two-tailed test of significance using SPSS 15 software at significance levels of $\mathrm{P} \leq 0.05$ and 0.001 . 


\section{Results and Discussions}

\subsection{Heavy Metal Contents}

$\mathrm{Mn}$ and $\mathrm{Ni}$ accumulations by L. gibba after 24, 48 and 72 hours of exposure is presented in Figure 1. The increased concentrations of $\mathrm{Mn}$ and $\mathrm{Ni}$ in the growing media caused an increase in the accumulations of metals by plants. Mn accumulation by $L$. gibba was higher than that of the $\mathrm{Ni}$ accumulation at each exposure concentration (except for $0.25 \mathrm{mg} / \mathrm{L}$ at $24 \mathrm{~h}$ ). Mn accumulated up to $15.150 \mathrm{mg} \mathrm{g}^{-1} \mathrm{D} . \mathrm{W}$. after $72 \mathrm{~h}$ at the 16 $\mathrm{mg} / \mathrm{L} \mathrm{Mn}$ exposure. However, Ni accumulated up to $1.874 \mathrm{mg} \mathrm{g}^{-1} \mathrm{D}$.W. at the same conditions. The potential role of aquatic plants (such as S. polyrhiza, C. demersum, L. gibba, L. minor, Myriophyllum heterophyllum, Nastrutium officinale and Elodea canadensis) on cleaning of heavy-metal contaminated waters due to their high metal-accumulation ability have been reported by several authors (Misra et al., 2006; Sivaci et al., 2007; Hou et al., 2007; Kara \& Zeytunluoglu, 2007; Maleva et al., 2009; Appenroth et al., 2010; Rolli et al., 2010). In agreement with other results in the literature, $L$. gibba has an ability to accumulate Mn. Therefore, $L$. gibba can be used as a phytoremediant for excess Mn due to its more efficient Mn uptake and accumulation potential compared to Ni.

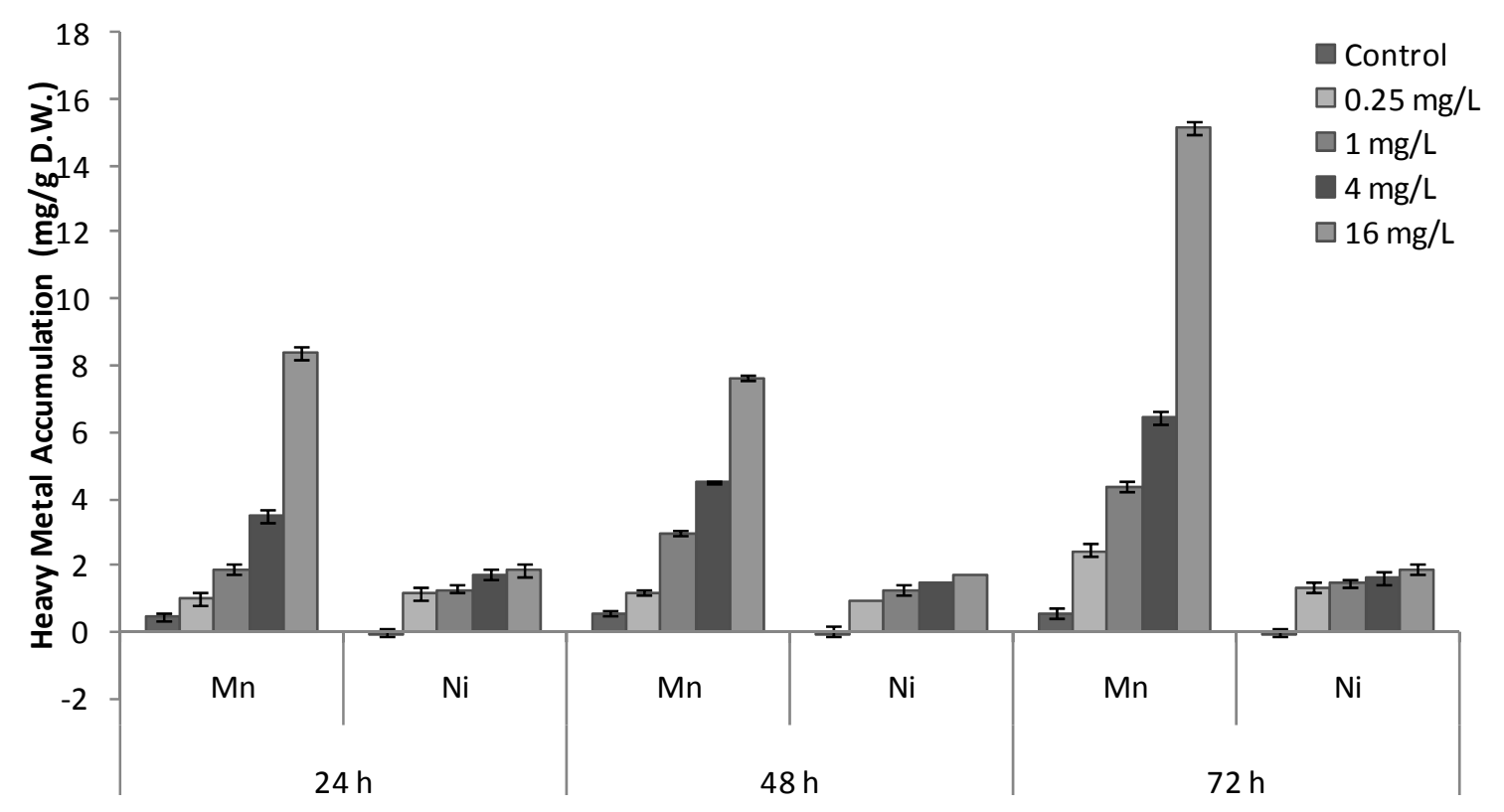

Figure 1. Mn and Ni accumulation by L. gibba at 24, 48 and 72 hours of treatment

\subsection{Photosynthetic Pigments}

There was no significant change in the pigments of both $\mathrm{Mn}$ - and Ni-exposed plants at $24 \mathrm{~h}$ of experiment $(\mathrm{Mn}$ : $\mathrm{F}_{\text {TotalChl }}=1.51, \mathrm{df}=4,10, p=0.271 ; \mathrm{F}_{\text {Car }}=0.95, \mathrm{df}=4,10, p=0.42 ; \mathrm{Ni}: \mathrm{F}_{\text {TotalChl }}=1.66, \mathrm{df}=4,10, p=0.233$; $\left.\mathrm{F}_{\mathrm{Car}}=1.63, \mathrm{df}=4,10, p=0.24\right)$. Pigment content of control plants increased during the experimental period (Figure 2). In addition, $\mathrm{Mn}$ and $\mathrm{Ni}$ exposure at low levels caused an increase in pigment content (Figure 2). Exposure time was positively correlated with $\mathrm{Car}\left(\mathrm{r}_{\mathrm{Mn}}=0.410\right.$ and $\left.\mathrm{r}_{\mathrm{Ni}}=0.338 \mathrm{p}=0.05\right)$ and Total $\mathrm{Chl}\left(\mathrm{r}_{\mathrm{Mn}}=\right.$ $0.212 \mathrm{p}=0.05$ ) contents of plants. Total $\mathrm{Chl}$ and Car contents were affected at $48 \mathrm{~h}$ after treatment in Ni-exposed plants. These parameters showed significant negative correlations with metal concentration $\left(\mathrm{r}_{\text {totalchl }}=-0.648 \mathrm{r}_{\mathrm{Car}}\right.$ $=-0.737 \mathrm{p}=0.01)$. However, Mn treatment caused significant changes in the pigment content only at $72 \mathrm{~h}$ and there were significant negative correlations between Mn concentration and pigment content $\left(\mathrm{r}_{\text {totalChl }}=-0.345 \mathrm{r}_{\text {Car }}\right.$ $=-0.417 \mathrm{p}=0.05$ ). Compared to the control, the highest decreases in total $\mathrm{Chl}$ and Car contents were determined at $16 \mathrm{mg} / \mathrm{L} \mathrm{Mn}$ at $72 \mathrm{~h}$ (total Chl 1.8-fold, Car 2.73-fold) and Ni concentrations at $48 \mathrm{~h}$ (total Chl 2.79-fold; Car 2.47-fold) after treatment, respectively. As seen in Figure 2, the fast and strong inhibition of total $\mathrm{Chl}$ and Car contents were determined in Ni-exposed plants than Mn-exposed plants.

The change in the pigment content in heavy metal exposed plants is one of the first visible symptoms. Additionally, these changes are used as an indicator for photosynthetic damage in plant tissues. In this study, Mn exposure caused increases in total $\mathrm{Chl}$ and Car contents at low concentrations. Although, $\mathrm{Mn}$ is an important microelement and is present as a constituent of enzymes and cofactors, it is toxic in excess concentrations. Mn is 
important for the Hill reaction of photosynthesis (Nusrat \& Rafiq, 2011). Furthermore, a mangano-protein is present for the water splitting system (Prasad \& Hegemayer, 1999). The increase in the pigment content of Mn-exposed plants at low levels might be attributed to play a precursor role of $\mathrm{Mn}$ in chlorophyll synthesis (Rezai \& Farboodina, 2008; Morgan et al., 1966). However, excess Mn can cause iron and magnesium deficiency due to its entry into porpyrin in the place of iron and magnesium (Sideris and Young, 1949). Reductions of photosynthetic pigments by excess Mn exposure were reported in both terrestrial plants, such as Pisum sativum (Rezai \& Farboodina, 2008; Gangwar et al., 2010), H. vulgare (Demirevska-Kepova et al., 2004), Glycine $\max (\mathrm{Wu}, 1994)$ and Phaseolus vulgaris (Gonzalez et al., 1998) and aquatic plants, such as $A$. caroliniana, S. minima and S. polyrhiza (Lizieri et al., 2011). Similar to Mn, Ni also caused an increase in the pigment amount at low levels. This increase in the pigment content could be regarded as the ability of the $L$. gibba plants to tolerate or overcome these low Ni concentrations. The significant decrease in the pigment content at $16 \mathrm{mg} / \mathrm{L}$ Ni-treatment could be due to nutrient imbalances caused by excess $\mathrm{Ni}$. The decrease in pigment content in plants exposed to excess Ni were demonstrated in Elodea canadensis (Maleva et al., 2009) and $L$. minor (Appenroth et al., 2010).
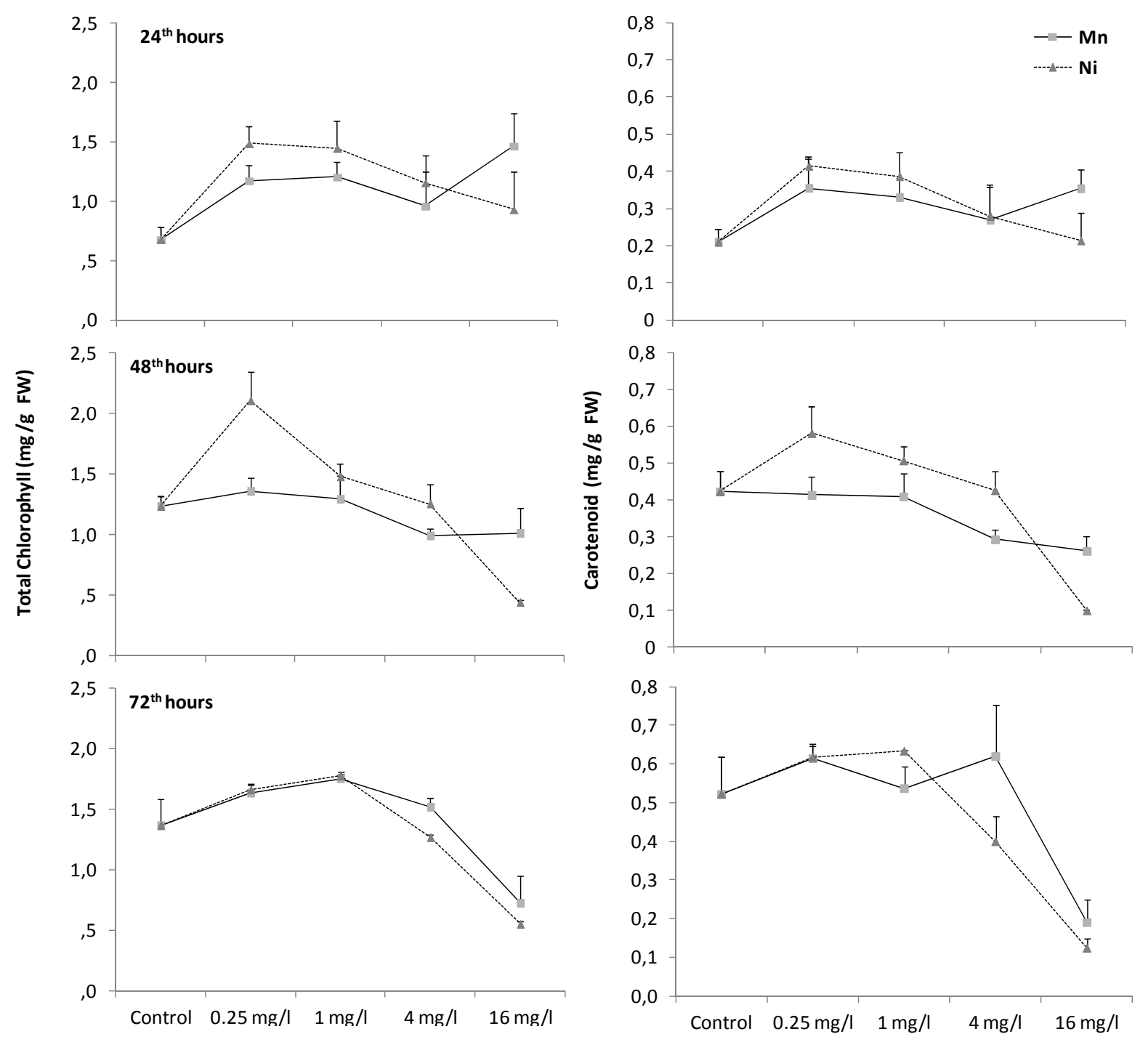

Figure 2. The effect of $\mathrm{Mn}$ and $\mathrm{Ni}$ exposure on the Total Chl and Car contents in L. gibbaafter 24, 48 and $72 \mathrm{~h}$ of exposure 


\subsection{Total Soluble Protein Content}

Protein content of the control plants ranged from $0.25-0.38 \mathrm{mg} / \mathrm{g} \mathrm{FW}$. Compared to the control, significant increases in the total soluble protein content were determined in Mn-treated plants at all treatment times (Figure $3)$. This was supported by correlations between protein content, exposure time and $\mathrm{Mn}$ accumulation $(\mathrm{r}=0.363 \mathrm{p}$ $=0.01)$. Ni exposure did not cause significant changes in the protein content at $24 \mathrm{~h}(\mathrm{~F}=1.393 \mathrm{df}=4,10, \mathrm{p}=$ 0.30). However, protein content showed distinctive increases of up to $4 \mathrm{mg} / \mathrm{L} \mathrm{Ni}$ in both 48 and $72 \mathrm{~h}$ after treatment (except for $0.25 \mathrm{mg} / \mathrm{L}$ at $48 \mathrm{~h}$ ). Compared with their respective controls, the maximum decreases were determined for $16 \mathrm{mg} / \mathrm{L}$ Ni-applied plants at $48 \mathrm{~h}$ (2-fold) and $72 \mathrm{~h}$ (1.8 fold) of experiment (Figure 3). Significant positive correlation was determined between exposure time and protein content in Ni-treated plants ( $\mathrm{r}$ $=0.376, \mathrm{p}=0.05)$.
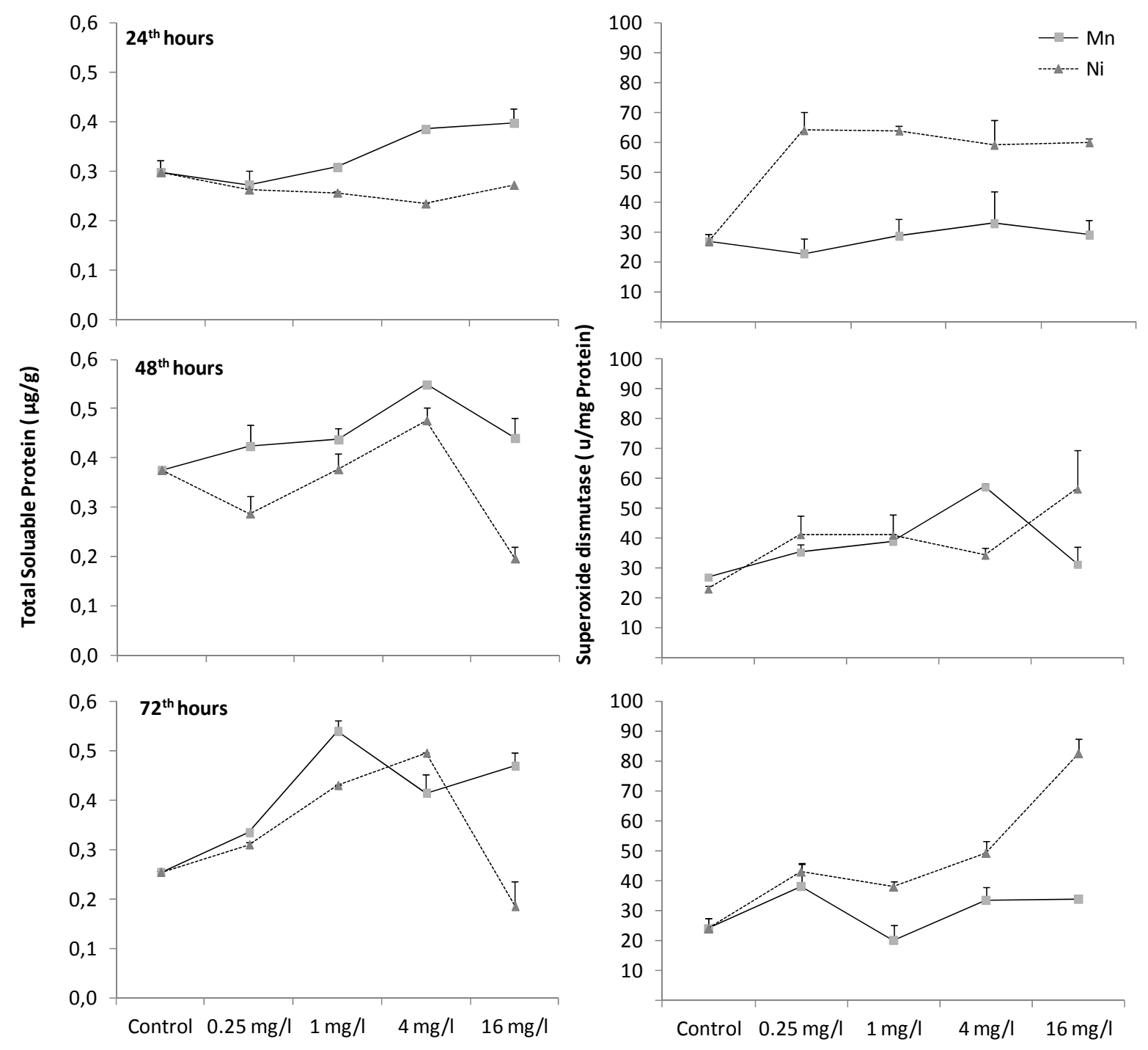

Figure 3. The effect of Mn and Ni exposure on the total soluble protein content and SOD activity in L. gibba after 24,48 and $72 \mathrm{~h}$ of exposure

Protein synthesis and breakdown were affected by toxic heavy metals in aquatic plants. Heavy metal induced increase in the reactive oxygen species can cause deleterious oxidation and degradation of proteins (Spychalla \& Desborough, 1990). Both decreases and increases in total protein content were reported in plants under heavy metal stress (Vajpayee et al., 2000; Lei et al., 2007). In this study, the decreasing amount of total soluble protein in the Ni-treated plants may be attributed to protein degradation due to oxidative damage. However, the increases in total protein content caused by the low concentration of $\mathrm{Ni}$ and by all the concentrations of $\mathrm{Mn}$ were probably 
due to the increase of specific stress-related proteins such as enzymes that are involved in antioxidant metabolism and phytochelatin biosynthesis (Lei et al., 2007). Changes in the total soluble protein contents have been shown as indicators for both the physiological status and reversible or irreversible metabolic changes of the plant (Piotrowska et al., 2010; Doganlar \& Atmaca, 2011). The significant decreases in total soluble protein content after $\mathrm{Ni}$ exposure in high doses could be explained by the disruption of metabolism in high heavy metal concentration and exposure time. With the application of the maximum dose of $\mathrm{Ni}$, there was a decrease in the total protein content. The reason for this decrease might be the damages that occurred in plant metabolism caused by high stress. Moreover, it may be said that the application of Mn to the plant may induce synthesis of some proteins related to stress to overcome the effects of heavy metal stress.

\subsection{SOD Activity}

Compared with the control, Ni treatment caused significant increases on the SOD activity at all treatment times (except for $48 \mathrm{~h}$ ). Both Ni exposure concentration and accumulation was positively correlated with SOD activity $\left(\mathrm{r}_{\mathrm{Ni} \text { concentration }}=0.342, \mathrm{r}_{\mathrm{Ni} \text { accumulation }}=0.307, \mathrm{p}=0.05\right)$. The highest increase in the SOD activity was detected at 16 $\mathrm{mg} / \mathrm{L}$ of Ni concentration at $72 \mathrm{~h}$ (Figure 3). Mn exposure did not cause a significant change in SOD activity 24 $\mathrm{h}$ after treatment. However, compared with control, increased SOD activities were detected at $48 \mathrm{~h}$ and $72 \mathrm{~h}$ (except for $16 \mathrm{mg} / \mathrm{L}$ at 48 and $1 \mathrm{mg} / \mathrm{L}$ at $72 \mathrm{~h}$ ). As seen in Figure 3, Ni-treated plants have higher SOD activity than Mn-treated plants (except for $4 \mathrm{mg} / \mathrm{L}$ metal exposure at $48 \mathrm{~h}$ ).

SOD is the first enzyme that is involved in the dismutation of the superoxide anion to oxygen and hydrogen peroxide at a very fast rate (Radic et al., 2010). Therefore, the changes in the activity of this enzyme are very important for overcoming the oxidative stress in plants. In the present study, increased SOD activity in Mn- and Ni-exposed plants was probably caused by the increase in superoxide anions. Additionally, the inducing effects of heavy metals on the increasing expression of SOD genes were demonstrated by Gao et al. (2009) in cucumber seedlings. Similar to our results, the stimulating effects of Mn and Ni on SOD activity were reported in Elodea canadensis, Vitis vinifera, Oryza sativa and Cucumis sativus (Maleva et al., 2009, Mour et al., 2011, Srivastava \& Dubey, 2011).

\subsection{POD Activity}

Compared to the control, Mn caused significant increases in the POD activity at all treatment times $(r=0.443 \mathrm{p}$ $=0.01$ ). POD activity was decreased with the increasing Ni concentration at $24 \mathrm{~h}$ and $48 \mathrm{~h}$ (except for $0.25 \mathrm{mg} / \mathrm{L}$ Ni) (Figure 4). However, POD activity was increased significantly at $72 \mathrm{~h}(\mathrm{~F}=34.072 \mathrm{df}=4,10 ; \mathrm{p}=0.001)$. These relationships were corrected by correlation analysis between $\mathrm{Ni}$ accumulation and POD activity $\left(\mathrm{r}_{24 \mathrm{~h}}=\right.$ $\left.-0.831 \mathrm{r}_{48 \mathrm{~h}}=-0.930, \mathrm{r}_{72 \mathrm{~h}}=0.693, \mathrm{p}=0.01\right)$. Compared to the control, the highest increases in the POD activity were determined at $48 \mathrm{~h}$ in the Mn-exposed plants at $1 \mathrm{mg} / \mathrm{L}$ (6.77 fold) and $72 \mathrm{~h}$ in Ni-exposed plants at $4 \mathrm{mg} / \mathrm{L}$ (6.9 fold). In general, the increase rate declined with the highest $\mathrm{Mn}$ and $\mathrm{Ni}$ concentrations.

Among the antioxidant enzymes, POD is the most important indicator for metal toxicity (Doganlar \& Atmaca, 2011). This enzyme is one of the major scavengers of hydrogen peroxide produced by cells under heavy metal stress. Because of $\mathrm{Mn}$ and Ni stress, significant deductibility of POD activity was reported in V. vinifera $(\mathrm{Mn})$, Pistia stratiotes (Ni), Citrus grandis (Mn), O. sativa (Mn), Zea mays (Ni) (Baccouch et al., 1998; Li et al., 2010; Mou et al., 2011; Singh \& Pandey, 2011; Srivastava \& Dubey, 2011). As seen from Figure 4, the increasing exposure time to both metals at different concentrations showed that the enzyme activity was more reduced at the dose of $16 \mathrm{mg} / \mathrm{L}$ than the other exposure doses in both heavy metals. These declines at the highest concentrations in POD activity may have resulted from the toxic effects of $\mathrm{Mn}$ and $\mathrm{Ni}$ on the synthesis and confirmation of enzyme activity (Sreedevi et al., 2008; Solanki et al., 2011). Additionally, the decrease in the POD activity may be due to increased activities of other detoxifiers of $\mathrm{H}_{2} \mathrm{O}_{2}$. This suggestion was confirmed by negative correlations between POD and CAT activities in both Mn- and Ni-exposed plants $\left(\mathrm{r}_{\mathrm{Ni2} 4}=-0.605 ; \mathrm{r}_{\mathrm{Mn} 24}=\right.$ $\left.-0.714 ; \mathrm{p}=0.01, \mathrm{r}_{\mathrm{Mn} 48}=-0.549, \mathrm{p}=0.05\right)$.

\subsection{CAT Activity}

Compared with the control, increased CAT activity was evidenced at all Ni concentrations except at $0.25 \mathrm{mg} / \mathrm{L}$ $\mathrm{Mn}$ in L. gibba $24 \mathrm{~h}$ after treatment (Figure 4). However, both Mn- and Ni-treatment caused increased CAT activity in $L$. gibba plants at $48 \mathrm{~h}$ and $72 \mathrm{~h}$. Additionally CAT activity increased with the Mn exposure time $(\mathrm{r}=$ $0.519 ; \mathrm{p}=0.05$ ). The highest increases in the CAT activity were determined at the $16 \mathrm{mg} / \mathrm{L} \mathrm{Mn} \mathrm{(3.76} \mathrm{fold)} \mathrm{and} 4$ $\mathrm{mg} / \mathrm{L} \mathrm{Ni}$ (4.85 fold) concentrations at $72 \mathrm{~h}$. Significant positive correlations were determined between metal accumulation and CAT activity in Ni- and Mn-treated plants $\left(\mathrm{r}_{\mathrm{Ni24}}=0.528 \mathrm{p}=0.05 ; \mathrm{r}_{\mathrm{Ni} 72}=0.842 ; \mathrm{p}=0.01 ; \mathrm{r}_{\mathrm{Mn} 48}\right.$ $\left.=0.520 ; \mathrm{p}=0.05 ; \mathrm{r}_{\mathrm{Mn} 72} 0.731 ; \mathrm{p}=0.01\right)$. 
CAT is one of the major $\mathrm{H}_{2} \mathrm{O}_{2}$ scavengers under heavy metal stress in plants. The increased activity of CAT in this study showed that $\mathrm{Mn}$ and $\mathrm{Ni}$ cause increasing amounts of hydrogen peroxide and additionally effective scavenging of $\mathrm{H}_{2} \mathrm{O}_{2}$. Our findings are in agreement with earlier reports showing the inducing effects of $\mathrm{Mn}$ and $\mathrm{Ni}$ on CAT activity in different plant species. The continuous increases in the CAT activity showed that $L$. gibba has a strong $\mathrm{H}_{2} \mathrm{O}_{2}$ scavenging capacity due to the activity of this enzyme in the Mn-exposed plants at $48 \mathrm{~h}$ and 72 h.
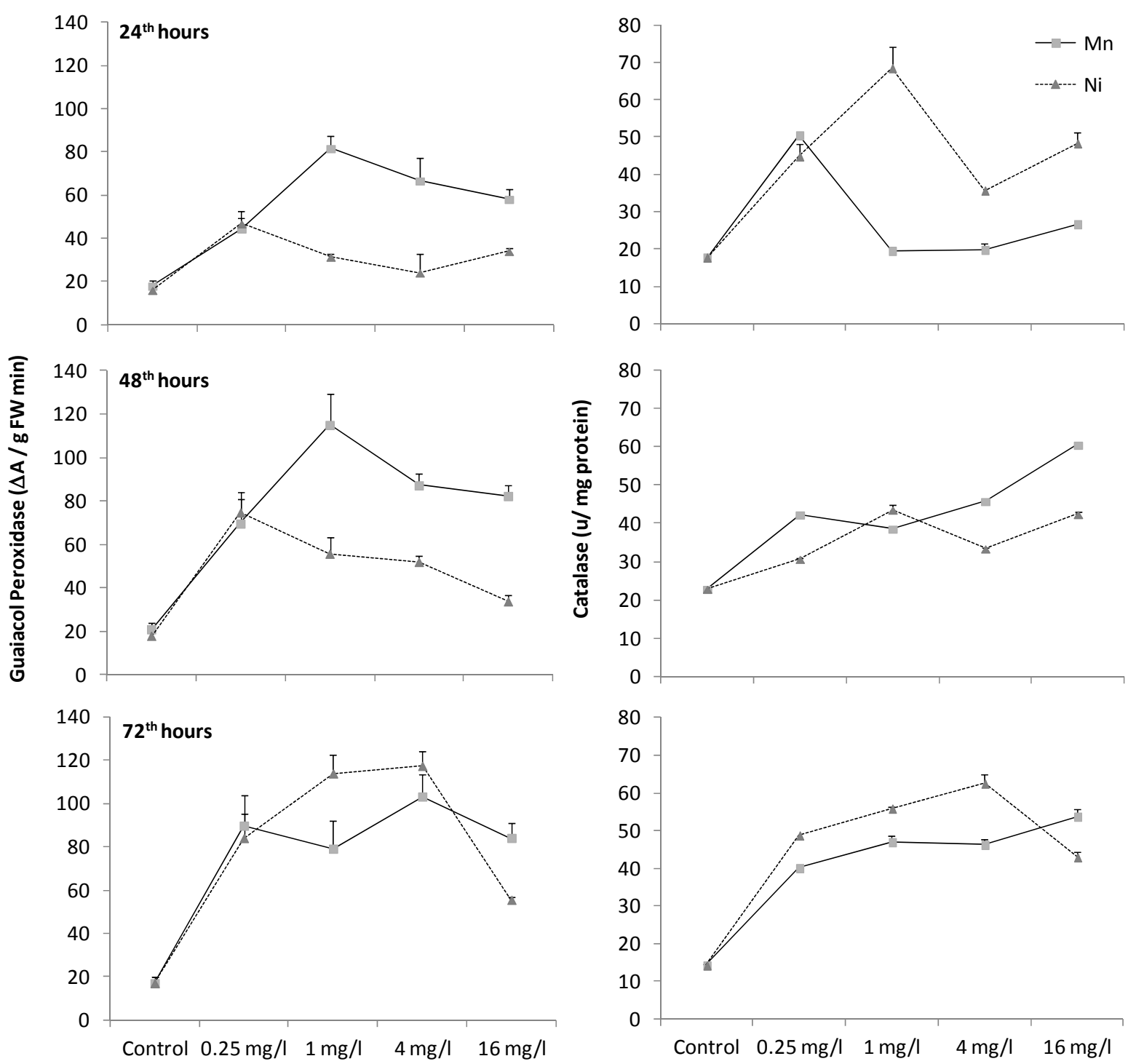

Figure 4.The effect of $\mathrm{Mn}$ and Ni exposure on the POD and CAT activity in L. gibba after 24, 48 and $72 \mathrm{~h}$ of exposure

\section{Conclusions}

According to the results presented here, the L. gibba can be used for cleaning of Mn polluted aquatic environments. Although both $\mathrm{Mn}$ and Ni cause significant changes in pigment, protein and antioxidant enzymes, Ni caused more pronounced toxicity symptoms. The decrease in pigment (total Chl and Car) and protein contents was evidenced at lower Ni concentrations and earlier exposure times than that of Mn. Additionally we can say that both heavy metals caused oxidative stress.

Although Mn accumulation was higher than $\mathrm{Ni}$, the symptoms of toxicity were lower for Mn than that of $\mathrm{Ni}$. The reason for this situation might be the effects of the antioxidant enzymes, especially POD to overcome the stress 
of the plant. Additionally, increasing amounts of protein content possibly due to increasing expression of stress proteins may have helped in inducing less toxicity symptoms for Mn.

\section{Acknowledgements}

The authors are grateful to Prof.Dr. Irfan ASLAN (Rector of Agri Ibrahim Cecen University, Agri/Turkey) and Agri Central Research and Application Laboratory which is funded by T.R. State Planning Organization (Project Number: 2010K120440) for providing laboratory equipments. The authors also wish to thank Assoc.Prof.Dr. Oguzhan Doganlar (Agri Ibrahim Cecen University, Agri, Turkey) for performing statistical analysis. This study was supported Agri Ibrahim Cecen University research project foundation (Project Number: BAP 2010-2/ Fen-02), Turkey

\section{References}

Aebi, H. (1984). Catalase in vitro. In: Methods Enzymol. Vol. 105, Packer L (Editor), pp 121-6. Academic Press, New York.

Appenroth, K. J., Krech, K., Keresztes, Á., Fischer, W., \& Koloczek, H. (2010). Effects of nickel on the chloroplasts of the duckweeds Spirodela polyrhiza and Lemna minor and their possible use in $\begin{array}{llll}\text { biomonitoring and } & \text { 216-223. }\end{array}$ http://dx.doi.org/10.1016/j.chemosphere.2009.11.007

Arnon, D. I. (1949). Copper enzymes in isolated chloroplasts, polphenoloxidase in Beta vulgaris. Plant Physiology, 24, 1-15. http://dx.doi.org/10.1104/pp.24.1.1

Azqueta, A, Shaposhnikov, S., \& Collins, A. R. (2009). DNA oxidation: investigating its key role in environmental mutagenesis with the comet assay. Mutation Research-Genetic Toxicology and Environmental Mutagenesis, 674, 101-108. http://dx.doi.org/10.1016/j.mrgentox.2008.10.013

Baccouch, S., Chaoui, A., \& El Ferjani, E. (1998). Nickel-induced oxidative damage and antioxidant responses in Zea mays shoots. Plant Physiol. Biochem, 36(9), 689-694. http://dx.doi.org/10.1016/S0981-9428(98)80018-1

Beuchamp, C., \& Fridovich, I. (1973). Isoenzymes of superoxide dismutase from wheat germ, Biochim. Biophys. Acta, 317, 50-64.

Birecka, H., Briber, K. A., \& Catalfama, J. L. (1973). Comparative studies on tobacco pith and sweet potato root isoperoxidases in relation to injury, indole acetic acid and ethylene effects. Plant Physiology, 52, 43-49. http://dx.doi.org/10.1104/pp.52.1.43

Bradford, M. M. (1976). A rapid and sensitive method for the quantitation of microgram quantities of protein utilizing the principle of protein-dye binding. Analytical Biochemistry, 72, 248-254. http://dx.doi.org/10.1016/0003-2697(76)90527-3

Chowdhury, M. J., Bucking, C., \& Wood, C. M. (2008). Is Nickel an Essential Metal for Aquatic Animals? Integr Environ Assess Manag, 4, 266-268.

Demirevska-Kepova, K., Simova-Stoilova, L., Stoyanova, Z., Hölzer R., \& Feller, U. (2004): Biochemical changes in barley plants after excessive supply of copper and manganese. Environmental and Experimental Botany, 52, 253-266. http://dx.doi.org/10.1016/j.envexpbot.2004.02.004

Doganlar Z. B. (2012). Quizalofop-p-ethyl-induced phytotoxicity and genotoxicity in Lemna minor and Lemna gibba. Journal of Environmental Science and Health, Part A 47, 1-13.

Doganlar, Z. B., \& Atmaca, M. (2011). Influence of Airborne Pollution on $\mathrm{Cd}, \mathrm{Zn}, \mathrm{Pb}, \mathrm{Cu}$, and $\mathrm{Al}$ accumulation and physiological parameters of plant leaves in Antakya (Turkey). Water, Air and Soil Pollution, 214, 509-523. http://dx.doi.org/10.1007/s11270-010-0442-9

Fargašová, A., nPastierová, J., \& Svetková, K. (2006). Effect of Se-metal pair combinations $(\mathrm{Cd}, \mathrm{Zn}, \mathrm{Cu}, \mathrm{Pb})$ on photosynthetic pigments production and metal accumulation in Sinapis alba L. Seedlings Plant Soil Environ, 52(1), 8-15.

Gangwar, S., Singh, V. P., Sheo Mohan Prasad, \& Jagat Narayan Maurya. (2010). Modulation of manganese toxicity in Pisum sativum L. seedlings by kinetin. Scienta Horticulturae, 126, 467-474. http://dx.doi.org/10.1016/j.scienta.2010.08.013

Gao, J. J., Li, T., \& Yu, X. (2009). Gene Expression and Activities of SOD in Cucumber Seedlings Were Related with Concentrations of $\mathrm{Mn}^{2+}, \mathrm{Cu}^{2+}$, or $\mathrm{Zn}^{2+}$ Under Low Temperature Stress Agricultural Sciences in China, 
$8(6), 678-684$.

Gonza'lez, A., Steffen, K. L., \& Lynch, J. P. (1998). Light and Excess Manganese Implications for Oxidative Stress in Common Bean. Plant Physiol, 118, 493-504. http://dx.doi.org/10.1104/pp.118.2.493

Hoagland, P. R, \& Arnon, D. I. (1950). The water culture method for growing plants without soil. California, College of Agriculture, Agricultural Experiment Statio, 347, 1-32.

Hou, W., Chen, X., Song, G., Wang, Q., \& Chang, C. C. (2007). Effects of copper and cadmium on heavy metal polluted waterbody restoration by duckweed (Lemna minor). Plant Physiology and Biochemistry, 45, 62-69. http://dx.doi.org/10.1016/j.plaphy.2006.12.005

James, P. S., \& Sharon, L. D. (1990). Superoxide Dismutase, Catalase, and a-Tocopherol Content of Stored Potato Tubers. Plant Physiol., 94, 1214-1218. http://dx.doi.org/10.1104/pp.94.3.1214

Jenner, H. A., \& Janssen-Mommen, P. M. (1993). Duckweed Lemna minor as a tool for testing toxicity of coal residues and polluted sediments. Archives of Environmental Contamination and Toxicology, 25, 3-11. http://dx.doi.org/10.1007/BF00230704

Kara, Y., \& Zeytunluoglu, A. (2007). Bioaccumulation of Toxic Metals ( $\mathrm{Cd}$ and $\mathrm{Cu}$ ) by Groenlandia densa (L.) fourr. Bulletin of Environmental Contamination and Toxicology, 6, 609-612. http://dx.doi.org/10.1007/s00128-007-9311-7

Li, Q., Chen, L. S., Jiang, H. X., Tang, N., Yang, L. T., Lin, Z. H., Li, Y., \& Yang, G. H. (2010). Effects of manganese-excess on $\mathrm{CO} 2$ assimilation, ribulose-1,5-bisphosphate carboxylase/oxygenase, carbohydrates and photosynthetic electron transport of leaves, and antioxidant systems of leaves and roots in Citrus grandis seedlings. BMC Plant Biol., 7, 10-42.

Lichtenthaler, H. K., \& Wellburn, A. R. (1983). Determinations of total carotenoids and chlorophylls a and b of leaf extracts in different solvents. Biochemical Society Transactions, 11, 591-592.

Lizieri, C., Aguiar, R., \& Kuki, K. N. (2011). Manganese accumulation and its effects on three tropical aquatic macrophytes: Azolla caroliniana, Salvinia minima and Spirodela polyrhiza Rodriguésia. 62(4), 909-917.

Maleva, M. G., Nekrasova, G. F., Malec, P., Prasad, M. N. V, \& Strzałka, K. (2009). Ecophysiological tolerance of Elodea canadensis to nickel exposure. Chemosphere, 77, 392-398. http://dx.doi.org/10.1016/j.chemosphere.2009.07.024

Megateli, S., Semsari, S., \& Couderchet, M. (2009). Toxicity and removal of heavy metals (cadmium, copper, and zinc) by Lemna gibba. Ecotoxicology and Environmental Safety, 72, 1774-1780. http://dx.doi.org/10.1016/j.ecoenv.2009.05.004

Millaleo, R., Reyes-Díaz, M., Ivanov, A. G., Mora, M. L., \& Alberdi, M. (2010) Manganese as essential and toxic element For plants: transport, accumulation and resistance mechanisms. J. Soil Sci. Plant Nutr., 10(4), 476-494.

Mishra, S., Srivastava, S., Tripathi, R. D., Kumar, R., Seth, C. S., \& Gupta, D. K. (2006). Lead detoxification by coontail (Ceratophyllum demersum L.) involves induction of phytochelatins and antioxidant system in

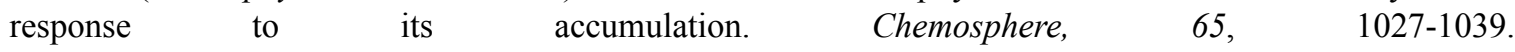
http://dx.doi.org/10.1016/j.chemosphere.2006.03.033

Morgan, P. W., Taylor, D. M., \& Joham, H. E. (1966). Effect of manganese toxicity on the indoleacetic acid oxidase system in cotton. Plant Physiol, 41, 718-724. http://dx.doi.org/10.1104/pp.41.4.718

Mou, D., Yao, Y., Yang, Y., Zhang, Y., Tian, C., \& Achal V. (2011). Plant high tolerance to excess manganese related with root growth, manganese distribution and antioxidative enzyme activity in three grape cultivars Ecotoxicology and Environmental Safety, 74, 776-786. http://dx.doi.org/10.1016/j.ecoenv.2010.10.040

Nusrat, J., \& Rafiq A. (2011). Effect of foliar-applied Boron and manganese on growth and biochemical activities in sunflower under saline conditions. Pak. J. Bot., 43(2), 1271-1282.

Parvaiz, A., Maryam, S., \& Satyawati, S. (2008). Reactive oxygen species, Antioxidants and signaling in plants. Journal of Plant Biology, 51, 167-173. http://dx.doi.org/10.1007/BF03030694

Piotrowska, A., Bajguz, A., Godlewska-Zyłkiewicz, B., \& Zambrzycka, E. (2010). Changes in growth, biochemical components, and antioxidant activity in aquatic plant Wolffia arrhiza (Lemnaceae) Exposed to Cadmium and Lead. Archives of Environmental Contamination and Toxicology, 58, 594-604. http://dx.doi.org/10.1007/s00244-009-9408-6 
Porgali, Z. B., \& Yurekli, F. (2005) Salt stres-induced alterations in proline accumulation, relative water content and superoxide dismutase (SOD) activity in salt sensitive Lycopersicon esculentum and L. pennellii. Acta Botanica Hungarica, 47(1-2), 173-182. http://dx.doi.org/10.1556/ABot.47.2005.1-2.15

Prasad, M. N. V., \& Hegemeyer, J. (1999). Heavy metal stress in plants: from molecules to ecosystems. Springer-Verlag, Berlin, 117-138.

Prasad, M. N. V., Malec, P., Waloszek, A., Bojko, M., \& Strzałka, K. (2001). Physiological responses of Lemna trisulca L. (duckweed) to cadmium and copper bioaccumulation. Plant Science, 161, 881-889. http://dx.doi.org/10.1016/S0168-9452(01)00478-2

Radić, S., Babić, M., Skobić, D., Roje, V., \& Pevalek-Kozlina, B. (2010). Ecotoxicological effects of aluminum and zinc on growth and antioxidants in Lemna minor L. Ecotoxicology and Environmental Safety, 73, 336-342.

Rezai, K., \& Farboodina, T. (2008). Manganese Toxicity Effects on Chlorophyll Content and Antioxidant Enzymes in Pea Plant (Pisum sativum L. c.v qazvin). Agricultural Journal, 3(6), 454-458.

Rolli, N. M., Suvarnakhandi, S. S., Mulgund, G. S., Ratageri, R. H., \& Taranath, T. C. (2010). Biochemical responses and accumulation of cadmium in Spirodela polyrhiza. Journal of Environmental Biology, 31, 529-532.

Shashi, K., \& Arya, B. K. (2011). Manganese induced changes in growth, chlorophyll content and antioxidants activity in seedlings of broad bean (Vicia faba L.). J. Environ. Biol., 32, 707-711.

Sideris, C. P. \& Young, H. Y. (1999). Growth and chemical composition of Ananas comosus L. in solution cultures with iron manganese ratios. Plant Physiol., 24, 416-421. http://dx.doi.org/10.1104/pp.24.3.416

Singh, K., \& Pandey, S. N. (2011). Effect of nickel-stresses on uptake, pigments and antioxidative responses of water lettuce, Pistia stratiotes L. J. Environ. Biol., 32, 391-394.

Sivaci, A., Elmas, E., Gumus, F., \& Sivaci, E. R. (2007). Removal of Cadmium by Myriophyllum heterophyllum Michx. and Potamogeton crispus L. and ,ts Effect on Pigments and Total Phenolic Compounds. Archives of Environmental Contamination and Toxicology, 54(4), 612-8. http://dx.doi.org/10.1007/s00244-007-9070-9

Solanki, R., Poonam, A., \& Dhankhar, D. (2011). Zinc and copper induced changes in physiological characteristics of Vigna mungo (L.) J. Environ. Biol., 32, 747-751.

Sreedevi, S., Krishnan, P. N., \& Pushpangadan, P. (2008). Cadmium induced oxidative stress and antioxidant responses in roots of black gram [Vigna mungo (L.) Hepper]. Ind. J. Plant Physiol., 13, 1-7.

Srivastava, S., \& Dubey, R. S. (2011). Manganese-excess induces oxidative stress, lowers the pool of antioxidants and elevates activities of key antioxidative enzymes in rice seedlings. Plant Growth Regulation, 64, 1-16. http://dx.doi.org/10.1007/s10725-010-9526-1

Vajpayee, P., Tripathi, R. D., Rai, U. N., Ali, M. B., \& Singh, S. N. (2000). Chromium (VI) accumulation reduces chlorophyll biosynthesis, nitrate reductase activity and protein content in Nymphaea alba L. Chemosphere, 41, 1075-1082. http://dx.doi.org/10.1016/S0045-6535(99)00426-9

Watt, R. K., \& Ludden, P. W. (1999). Nickel-binding proteins. Cell. Mol. Life Sci., 56, 604-625. http://dx.doi.org/10.1007/s000180050456

$\mathrm{Wu}$, J. D. (1994). Effect of manganese excess on the soybean plant cultivated under various growth conditions. Journal of Plant Nutrition, 17, 991-1003. http://dx.doi.org/10.1080/01904169409364783

Yanbao, L., Ke, C., Xiangrong, T., Helena K., \& Chunyang, L. (2007). Effect of Mn toxicity on morphological and physiological changes in two Populus cathayana populations originating from different habitats Trees. 21, 569-580. http://dx.doi.org/10.1007/s00468-007-0152-0

Zengin, F. K., \& Munzuroglu, O. (2005). The Effects of Some Heavy Metals $\left(\mathrm{Ni}^{2+}, \mathrm{Co}^{2}+, \mathrm{Cr}^{3+}\right.$ and $\left.\mathrm{Zn}^{2+}\right)$ on the Amount of Chlorophyll and Carotenoid in Bean (Phaseolus vulgaris L. Strike) Seedlings. Science and Engineering Journal of Firat University, 17(1), 164-172. 